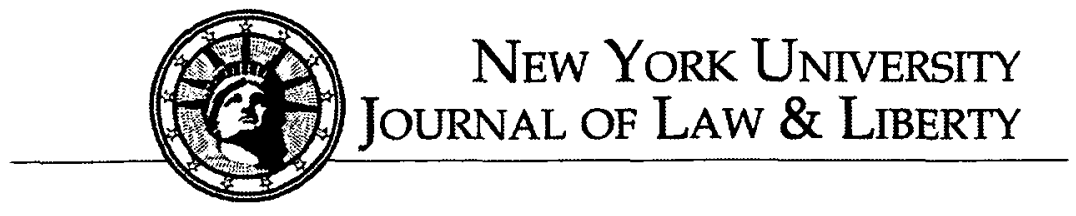

\title{
NOEL CANNING V. NLRB: SHOULD COURTS POLICE THE RECESS APPOINTMENTS POWER?
}

\section{Peter M. Shane*}

"Differences between the President and the Congress are commonplace under our system. The differences should, and almost invariably do, turn on political rather than legal considerations. The Judicial Branch should not decide issues affecting the allocation of power between the President and Congress until the political branches reach a constitutional impasse."

-Justice Lewis Powell ${ }^{1}$

- Jacob E. Davis and Jacob E. Davis II Chair in Law at Ohio State University's Moritz College of Law. Portions of this essay are excerpted from Peter M: Shane, In NLRB Recess Appointments Case, Roberts Court Can Now Show It Knows How to Exercise Judicial Restraint, BLOOMBERG BNA DAILY REPORT FOR EXECUTIVES B1-B4 July 29, 2013); Peter M. Shane, NLRB v. New Vista Nursing and Rehabilitation: The Third Circuit Further Fuels the Constitutional Conflict Over Recess Appointments, BLOOMBERG BNA DAILY REPORT FOR EXECUTIVES B1-B5 (May 24, 2013); and Peter M. Shane, The Future of Recess Appointments in Light of Noel Canning v. NLRB, BLOOMBERG BNA DAILY REPORT FOR EXECUTTVES B1-B5 (May 14, 2013).

${ }^{1}$ Goldwater v. Carter, 444 U.S. 996, 997 (1949) (Powell, J., concurring). 


\section{INTRODUCTION}

In Noel Canning $v \cdot N L R B,{ }^{2}$ the Supreme Court appears poised to decide an issue with potentially profound consequences for the dynamics of executive-legislative interaction-namely, the scope of the President's recess appointments power. In January 2013, a panel of the U.S. Court of Appeals for the District of Columbia Circuit invalidated President Obama's January 2012 recess appointments for three members of the National Labor Relations Board (NLRB). The panel unanimously concluded that the recess appointments power was available to presidents only between sessions of Congress. Two of the three judges went further. They interpreted the recess appointments power as applying only to offices that first become vacant between sessions of Congress. The first of these holdings calls into question the legality of innumerable actions by well over 300 federal officials who, since 1981, received recess appointments during congressional sessions. ${ }^{3}$ The second holding would likely invalidate most of the more than 300 additional recess appointments that presidents since Reagan have made between congressional sessions.

As discussed below, the D.C. Circuit's reasoning was singularly unpersuasive. That does not preclude the Supreme Court, however, from upholding the Court of Appeals judgment on other grounds. In fact, there are at least five plausible outcomes on the merits in the Supreme Court, each of which can claim some support in separation of powers law and practice. After explaining the facts of Noel Canning, this essay will lay out the alternatives and argue that the Court should heed Justice Powell's 1979 admonition and back off.

2705 F.3d 490 (D.C. Cir. 2013).

${ }^{3}$ HenRY Hogue, et AL., CONG. Research SeRv., The Noel CanNING DeCision AND RECESS APPOINTMENTS MADE FROM 1981-2013, at 4 (2013) (tabulating presidential recess appointments since 1981). 


\section{THE NLRB RECESS APPOINTMENTS}

The Noel Canning decision arose in the context of an ongoing struggle between presidents and Congress over the use of the recess appointments power. The Constitution conveys that power in a paragraph that authorizes the President "to fill up all vacancies that may happen during the recess of the Senate, by granting commissions which shall expire at the end of their next session." 4

When the Democrats regained control of the Senate in 2007, they began a practice of conducting so-called "pro forma sessions" during those recesses that occur within sessions of Congress. These pro forma sessions typically last only a couple of minutes, if that, during which the only business conducted - often by a single Senator-is simply a call to order and adjournment until the next pro forma session. Senate Majority Leader Harry Reid (D-NV) - now a supporter of the contested Obama appointments-originally took the position that such pro forma sessions converted otherwise lengthy recesses into shorter adjournments, each of which would be too brief to trigger the President's recess appointments power. ${ }^{5}$ Although apparently advised by the Justice Department that his recess appointments power remained intact, ${ }^{6}$ President George W. Bush declined to challenge the Reid strategy.

${ }^{4}$ U.S. CONST. art. II, § 2, cl. 3.

${ }^{5}$ Lawfulness of Recess Appointments During a Recess of the Senate Notwithstanding Periodic Pro Forma Sessions, 2012 WL 168645, at 2 (O.L.C. 2012) [hereinafter, OLC Recess Appointments Opinion], (citing 154 Cong. Rec. 57558 (daily ed. July 28, 2008) (statement of Sen. Reid), and 153 Cong. Rec. S14609 (daily ed. Nov. 16, 2007) (statement of Sen. Reid) ("TT]he Senate will be coming in for pro forma sessions . . . to prevent recess appointments.")).

${ }^{6} I d$. at 4 (citing Memorandum to File, from John P. Elwood, Deputy Assistant Attorney General, Office of Legal Counsel, Re: Lawfulness of Making Recess Appointment During Adjournment of the Senate Notwithstanding Periodic "Pro Forma Sessions" (Jan. 9, 2009)). 
Between December 17, 2011 and January 23, 2012, the Senate again met only during ten pro forma sessions - but this time not at the Democrats' behest. Article I, $\S 5$ of the Constitution provides that "[n]either House, during the session of Congress, shall, without the consent of the other, adjourn for more than three days ...." The evident purpose of this clause is to enable each House to keep the other in town in order to assure that business between them may be conducted. House Republicans, however - who were by no means staying in town to conduct business of their own-used this clause to deny the Senate permission to adjourn for more than three days between the end of the first and the start of the second session of the $112^{\text {th }}$ Congress. The intent, once again, was to block presidential recess appointments.

Against this procedural background, President Obama faced a late 2011 administrative crisis involving two federal agencies. President Obama had nominated labor attorney Craig Becker to the NLRB on July 9, 2009. When Senate Republicans filibustered Becker's confirmation vote, Obama gave him a recess appointment to the Board over eight months later, on March 28, 2010 - an intrasession appointment the constitutionality of which itself has been challenged in two other cases. ${ }^{7}$ President Obama resubmitted the nomination on January 26, 2011, but the Republicans persisted in their filibuster. Republicans also prevented a vote on a second January 2011 nominee, Terrence F. Flynn.

As a result of the filibuster, the NLRB was facing a calamity brought on by the Supreme Court's 2010 decision in a case called New Process Steel $v$. NLRB. ${ }^{8}$ The Court there interpreted the National Labor Relations Act to require three lawfully participating members

${ }^{7}$ NLRB v. New Vista Nursing and Rehabilitation, 719 F.3d 203 (3d Cir. 2013); NLRB v. Enterprise Leasing Company Southeast, LLC, 722 F.3d 609 (3d Cir. 2013).

${ }^{8}$ New Process Steel v. NLRB, 130 S. Ct. 2635 (2010). 
to be in place in order for the NLRB to act. The expiration of the 2010 Becker recess appointment threatened to reduce the Board's membership to two. Thus, on December 14, 2011, President Obama withdrew the Becker nomination and forwarded to the Senate nominations for Sharon Block and Richard F. Griffin Jr. When the Senate predictably did not act on these nominations by the end of the first session of the $112^{\text {th }}$ Congress, President Obama set the stage for Noel Canning v. NLRB by giving recess appointments to Block and Griffin-and to Terrence F. Flynn - on January $4,2012 .{ }^{9}$

\section{THE COURT's REASONING IN NOEL CANNING}

Noel Canning, a Pepsi-Cola bottling firm in Yakima, Washington, sued in the D.C. Circuit to overturn an NLRB order finding that management had unlawfully refused to enter into a collective bargaining agreement with the Teamsters local representing its production employees. A panel comprising Judges David Sentelle, Karen Henderson, and Tom Griffith-appointees of Presidents Reagan, Bush 41 and Bush 43, respectively-concluded that the NLRB's decision was legally supportable, but that it could not be enforced. The panel held that the Obama recess appointments were invalid and that, without them, the NLRB lacked the necessary quorum to conduct business.

${ }^{9}$ Although the Noel Canning decision technically dealt only with these three NLRB appointments, President Obama also made a fourth recess appointment on January 4, 2012. He appointed Richard Cordray to head the Consumer Financial Protection Bureau (CFPB) created by the Dodd-Frank Act. The Senate had sat on the Cordray nomination since July 18, 2011, because of Republican hopes to force an amendment to the Act that would convert the CFPB into a multi-member commission. Because the Dodd-Frank Act conditions certain of the agency's powers on the appointment of the agency head, 12 U.S.C. $\$ 5586(\mathrm{a})$, a vacancy in the Director's position would disable the CFPB from carrying out a number of its significant supervisory, enforcement, and rulemaking powers. 
Judge Sentelle's opinion for the court reached its conclusion based on what it took to be the original "public meaning" of the Recess Appointments Clause. The panel determined that the phrase "the recess" in that clause would have been understood in the late $18^{\text {th }}$ century to refer only to the period of adjournment between two sessions of Congress. Because the second session of the $112^{\text {th }}$ Congress convened on January 3,2012, the court reasoned that appointments made on January 4 were impermissible "intrasession" appointments. ${ }^{10}$

Judge Sentelle went on to argue further, with only Judge Henderson concurring, that the original meaning of "happen" in the Recess Appointments Clause was "to occur." For that reason, he wrote, the Recess Appointments Clause, properly read, would allow presidents to fill only those vacancies that first arise during recesses between sessions of Congress. ${ }^{11}$ Under this reasoning, the President could not legally fill a vacancy created by an official's death even one day prior to the Senate's adjournment, no matter how long the Senate remained in recess.

Perhaps the one safe prediction regarding the Supreme Court review is that the Court will not affirm this second holding. The text does not compel it. History refutes it. Presidents since the 1820s have consistently taken the position that vacancies "happen" during a recess of the Senate if they "happen to exist" during that recess. Congress itself effectively ratified that position in enacting the so-called Pay Act, ${ }^{12}$ which allows recess appointees to receive their salaries even if they were appointed to vacancies that occurred when the Senate was in session. The narrow reading of "happen"

\footnotetext{
${ }^{10}$ Noel Canning v. NLRB, 705 F.3d 490, 499-507 (D.C. Cir. 2013).

${ }^{11}$ Id. at 507-514.

125 U.S.C $\$ 5503$ (2013).
} 
on which Noel Canning relies has been rejected by earlier opinions of the Second, ${ }^{13}$ Ninth, ${ }^{14}$ and Eleventh ${ }^{15}$ Circuits. It is also glaring that reading "happen" more narrowly would lack any plausible functional justification. If government would be disabled by a vacancy left unfilled during a Senate recess, it could hardly make any difference when that vacancy first arose.

The permissibility of intrasession appointments is a closer question, and it is more difficult to predict how the Supreme Court will resolve it. Nonetheless, the D.C. Circuit's particular analysis-its assertion that the 1789 "public meaning" of the recess appointments clause compels its conclusion - is unpersuasive. In reaching the same bottom-line conclusion regarding the 2010 Craig Becker intrasession appointment, the Third Circuit pointedly rejected the D.C. Circuit analysis: "[R]ecess had at least two meanings at the time of ratification: either intersession breaks only or intersession breaks plus long intrasession breaks." 16 Presidents have consistently asserted authority to make intrasession appointments since 1921 . And, as noted earlier, intrasession recess appointments have been as common since the first Reagan Administration as intersession appointments. The Eleventh Circuit upheld their legality in Evans $v$. Stephens. ${ }^{17}$

What is likely to govern the Court's disposition of this issue - if it reaches it -is what the Court takes to be the dominant principle underlying the design of the constitutional appointments process. The other courts of appeals that have invalidated intrasession appointments have done so on the ground that allowing such ap-

13 United States v. Allocco, 305 F.2d 704 (2d Cir. 1962).

${ }^{14}$ United States v. Woodley, 751 F.2d 1008 (9th Cir. 1985).

${ }^{15}$ Evans v. Stephens, 387 F.3d 1220 (11th Cir. 2004).

${ }^{16}$ NLRB v. New Vista Nursing and Rehabilitation, 719 F.3d 203, 266 (3d Cir. 2013).

${ }^{17} 387$ F.3d 1220 (11 ${ }^{\text {th }}$ Cir. 2004). 
pointments runs too great a risk of subverting the advice-andconsent process as the primary or ordinary mode for appointment. ${ }^{18}$

What this analysis overlooks, however, is that the Constitution intends that presidents, not the Senate, take the leading role in staffing the executive branch. Urging New Yorkers to ratify the Constitution, Alexander Hamilton explained the design of the appointments process in these terms: "[O]ne man of discernment is better fitted to analyze and estimate the peculiar qualities adapted to particular offices, than a body of men of equal or perhaps even of superior discernment." 19 The Senate was given a role in the appointments process not to impede the President's policy agenda, but as a check on potential corruption: "[The Senate] would be an excellent check upon a spirit of favoritism in the President, and would tend greatly to prevent the appointment of unfit characters from State prejudice, from family connection, from personal attachment, or from a view to popularity." 20 Advice-and-consent appointments were no doubt intended to be the ordinary or primary mode of proceeding, but protecting the Senate's confirmation role at the expense of the President's appointments responsibility turns the constitutional design on its head. Presidents-who are constitutionally charged to "take Care that the Laws be faithfully executed" 21 could be stymied permanently in the execution of their administrative responsibilities by a Senate minority determined to block appointments.

${ }^{18}$ NLRB, v. New Vista Nursing and Rehabilitation, 719 F.3d 203, 229 (3d Cir. 2013); NLRB v. Enterprise Leasing Company Southeast, LLC, 722 F.3d 609, 655 (3d Cir. 2013).

${ }^{19}$ THE FEDERALIST, No. 76 (Alexander Hamilton).

${ }^{20} \mathrm{Id}$.

${ }^{21}$ U.S. CONST. art. II, $\$ 3$. 


\section{SiX Plausible SCENARIOS}

Given the complex fact pattern involved in Noel Canning, as well as the uncertainty of the underlying constitutional issue, it is possible to imagine at least six plausible Supreme Court approaches, none of which would be entirely out of step with the overall body of separation of powers jurisprudence.

\section{BAR INTRASESSION RECESS APPOINTMENTS.}

The Court might decide that the D.C. Circuit was correct on the invalidity of intrasession appointments, even if it thought the lower court's textual analysis overdrawn. Should the Court think it violative of the Framers' design to permit the President too easily to circumvent the ordinary advice-and-consent process, the Court might limit presidential power to intersession appointments only. Should it do so, it would presumably vacate the lower court's holding on the "happen" issue, the resolution of which was unnecessary to the outcome.

There are two obvious reasons, however, for the Court to eschew this approach-aside from the originalist counterargument elaborated above. First, it could substantially weaken the presidency in competition for policy influence with the Senate, and the Roberts Court is likely to be friendly to executive power. Second, although barring intrasession appointments could limit the times for recess appointments, it might have no bearing on their frequency. Theodore Roosevelt used a moment's intersession recess in 1903 to make 193 executive branch appointments, literally between two 
raps of a gavel.22 A President intending to circumvent the ordinary process could incontestably resort to this maneuver.

\section{INVALIDATE INTRASESSION APPOINTMENTS BETWEEN PRO FORMA SESSIONS.}

The Supreme Court could uphold the D.C. Circuit's judgment by addressing an issue that the lower court ignored-namely, the impact of the pro forma sessions. That is, without necessarily deciding one way or the other about intrasession appointments as a general matter, the Court could decide: (a) periods of adjournment three days or shorter are too short to be deemed intrasession "recesses," and (b) the Senate's pro forma sessions effectively divided what would otherwise have been a three-week recess into these short, appointments-proof periods of adjournment. On its own motion, the Court added the pro forma session issue to the questions presented on certiorari.

This route would be a tempting option for a court intent on a narrow holding, but the Court is not really in a position to deflect the larger issue of intrasession appointments. That is because the Third and Fourth Circuit opinions invalidating Craig Becker's recess appointment did not involve any issue of pro forma sessions. Were the Court to take these up, it could not dodge the more sensitive issue.

The other problem, of course, is that there is no textual basis for a three-day lower-limit on what counts as an intrasession recess. Three days is the number of days either House may adjourn without the consent of the other, but that seems utterly irrelevant to the

${ }^{22}$ Al Kamen, Recess Appointments: Nobody Did Them Like Teddy, WASH. POST., Dec. 12, 2011, http://www.washingtonpost.com/blogs/in-the-loop/post/recess-appoint ments-nobody-did-them-like-teddy/ 2011/12/08/gIQAJK1IgO_blog.html. 
question of what counts as a "recess." Historically, the executive branch has operated under an informal norm that three days is too short, but norms are not binding. The Court would be cutting a three-day rule from whole cloth.

\section{UPHOLD THE APPOINTMENTS ON THE GROUND THAT THE SENATE WAS DE FACTO IN AN INTERSESSION RECESS.}

Former Senate Legal Counsel Michael Davidson has urged rather ingeniously that the Court could dodge the intrasession appointments issue by deeming the NLRB appointments to be de facto intersession appointments. The crux of his argument is as follows:

The January 4, 2012 recess appointments were made during a break that began in fact with conclusion of the work of the first session of the 112th Congress on December 23, 2011 (or, in any event, by noon on January 3, 2012). That break which featured no business, no quorums, no duty at all to attend, extended in fact until a quorum assembled in the House on January 17 and in the Senate on January 23, 2012 to begin the work of the second session of the 112th Congress. In light of the requirement of the Twentieth Amendment that the Congress "assemble" to begin its annual meeting, ... the "no business" period which preceded the actual assembly of Congress [could] be understood to be within "the recess" during which a recess appointment may be made. ${ }^{23}$

${ }^{23}$ Michael Davidson, Why It Is Neither Necessary Nor Desirable To Go To Either Of The Extremes Now Presented In NLRB v. Noel Canning: The Significance Of The Annual Meeting Clause, Aug. 8, 2013, available at http://www.constitutionproject.org/wpcontent/uploads/2013/08/Davidson-TCP-Web-Post-8.8.13.pdf. 
In other words, by delaying its respective houses' business until January 23, Congress failed to "assemble" until that date. Without "assembly," the new Session of Congress should not be deemed to have started. The NLRB appointments thus occurred between the actual end of business of one session and the start of business for another - that is, during an intersession recess.

This, too, would be an admirable dodge of the larger constitutional issues-except that it would not work for the Third and Fourth Circuit cases for which review would also be sought. The Court's respite from tackling the harder issue would be brief. This argument would also pose the odd difficulty that, even while granting the NLRB a victory, the Court would be invalidating a portion of the time that the recess appointees served. That is, if January 3 , 2012 were deemed part of a recess between the end of the $112^{\text {th }}$ Congress and the start of the $113^{\text {th }}$, then the January 3 recess appointments would be valid until only the end of the first session of the $113^{\text {th }}$ Congress. If they were valid "intrasession" appointments during the first session of the $113^{\text {th }}$ Congress, then they would be effective through the end of the second session in 2013.

4. UPHOLD INTRASESSION APPOINTMENTS IN GENERAL AND FIND THE PRO FORMA SESSIONS INEFFECTIVE.

Based on the importance of preserving presidential priority in the appointments process, the Court might read the ambiguities of the Recess Appointments Clause in favor of the President. It could avoid deciding whether any lower limit exists as to the length of adjournment that is constitutionally eligible to count as a recess by holding that (a) whatever any such limit might be, 20 days is long 
enough, and (b) the pro forma sessions were ineffective in turning the 20-day recess into shorter breaks for appointments purposes. This would amount to the least destabilizing holding in that it would essentially ratify what had been stable practice for nearly the last century, prior to the use of the pro forma sessions. Putting the Court's explicit imprimatur on intrasession appointments, however, might actually embolden future presidents to use them more. The norm against their use has probably been stronger than it would otherwise be because of their uncertain constitutional status.

\section{UPHOLD INTRASESSION APPOINTMENTS WITHOUT REGARD TO LENGTH OF ADJOURNMENT.}

Hypothetically, the Court might also decide that intrasession recess appointments are permissible and that the length of adjournment sufficient to count as a recess amounts to a nonjusticiable political question. However far this would go in buttressing the President's institutional position vis-à-vis appointments, there is, in fact, no textual basis for any particular time limit. Such a holding, in principle, might seem to sanction recess appointments even during a lunch break. However, there seems no realistic political prospect of such behavior, and "[a] system of separate and coordinate powers necessarily involves an acceptance of exclusive power that can theoretically be abused." 24

\section{AVOID RULING ON THE MERITS.}

Finally, the Court might use either of two routes to avoid any substantive ruling on recess appointments. On July 30, 2013, the

${ }^{24}$ Morrison v. Olson, 487 U.S. 654, 710 (1988) (Scalia, J., dissenting). 
Senate finally did confirm a full roster of NLRB members. ${ }^{25}$ The Court could remand Noel Canning to the NLRB for re-hearing should Noel Canning so request it. Because the NLRB members then in place will all hold office under fully confirmed appointments, any decision they then render will be free of constitutional infirmity. Alternatively, the Court could decide that the key legal issues presented regarding the interpretation of the recess appointments power are all "political questions" - that is, questions that the Court regards as constitutionally left to the elected branches of government to decide for themselves. Either way, the Supreme Court would be leaving the recess appointments controversy where it belongs - to the elected branches of government.

Such a display of judicial restraint would be entirely welcome. First, unlike separation of powers cases that the Court has resolved-cases like Youngstown Steel, ${ }^{26}$ Chadha, ${ }^{27}$ or Boumediene ${ }^{28}-$ Noel Canning presents no issue with any direct connection to individual rights or liberties. That is, there is no reason to think that the fact of recess appointment during a Senate session, as opposed to between Senate sessions, gives a private party before the NLRB a hearing that is any less fair, robust, or respectful of the law. Life, liberty and property are simply not at issue.

${ }^{25}$ Ramsey Cox, Senate Confirms All Five NLRB members, THE HILL, July 30, 2013, http:/ / thehill.com/blogs/floor-action/senate/314503-senate-votes-to-confirm-allfive-nlrb-members.

${ }^{26}$ Youngstown Sheet \& Tube Co. v. Sawyer, 343 U.S. 579 (1952) (overturning President Truman's seizure of the steel mills as going beyond the scope of unilateral presidential authority).

${ }^{27}$ I.N.S. v. Chadha, 462 U.S. 919 (1983) (invalidating Congress's exercise of a oneHouse legislative veto as a violation of the Constitution's Presentment Clauses and bicameralism requirement).

${ }^{28}$ Boumediene v. Bush, 553 U.S. 723 (2008) (holding Congress without authority to suspend habeas corpus for alleged enemy combatants held in custody at Guantanamo). 
Moreover, the Court is confronted with "a dispute between coequal branches of our Government, each of which has resources available to protect and assert its interests, resources not available to private litigants outside the judicial forum." 29 Where the Constitution assigns to the elected branches a shared power, as with treaties or appointments, the Court behaves wisely in allowing each branch's political and institutional incentives and disincentives to operate, as they were intended, to curb overreach by the other branch.

${ }^{29}$ Goldwater v. Carter, 444 U.S. 996, 1004 (1949) (Rehnquist, J., concurring in the judgment). 